\title{
First record of the genus Stenogiffardia (Auchenorrhyncha: Cicadellidae) from Madagascar, with description of a new species and a key to species
}

\author{
Vladimir M. GNEZDILOV \\ Zoological Institute of the Russian Academy of Sciences, Universitetskaya nab. 1, 199034, Saint Petersburg, Russia; \\ e-mail: vmgnezdilov@mail.ru,vgnezdilov@zin.ru
}

\author{
Accepted: \\ $2^{\text {nd }}$ December 2019 \\ Published online: \\ $27^{\text {th }}$ December 2019
}

\begin{abstract}
Stenogiffardia bifurca sp. nov. is described from a series of specimens collected in the former Antananarivo, Fianarantsoa, and Toliara Provinces of Madagascar. This is the first record of the genus Stenogiffardia Evans, 1977 (Hemiptera: Cicadellidae: Deltocephalinae) from Madagascar, which is now the third genus of the tribe Chiasmini known from the island. The distribution of Stenogiffardia is analyzed and an identification key to species is given. Stenogiffardia elongata Evans, 1977 is removed from synonymy with S. parvula (Kirkaldy, 1906).
\end{abstract}

Key words. Hemiptera, Cicadomorpha, Membracoidea, Deltocephalinae, Chiasmini, leafhopper, morphology, taxonomy, transoceanic distribution, Madagascar

\footnotetext{
Zoobank: http://zoobank.org/urn:lsid:zoobank.org:pub:4EA1C168-8D63-4DCF-94C2-F05330089B8C

(C) 2019 The Authors. This work is licensed under the Creative Commons Attribution-NonCommercial-NoDerivs 3.0 Licence.
}

\section{Introduction}

During a field trip to Madagascar in January 2011 organized by the association "Naturevolution" for the study of nature of the Makay Massif (GNEZDILOv 2015), a series of specimens representing a new species of the genus Stenogiffardia Evans, 1977 was collected in the former Antananarivo, Fianarantsoa, and Toliara Provinces (Figs 1-4), together with other materials of Auchenorrhyncha which are mostly still unidentified. So far, only the paper on subbrachypterous Ricaniidae (Fulgoroidea) has been published based partly on specimens from this expedition (STROIŃSKI et al. 2011). The new species described below is from the subfamily Deltocephalinae of the family Cicadellidae, which is an extremely diverse and species-rich group of leafhoppers (ZAHNISER \& DiETRICH 2013), well represented in all kinds of biotopes in Madagascar, including urban areas.

The genus Stenogiffardia Evans, 1977 belongs to the grass-specialist tribe Chiasmini Distant, 1908, distributed worldwide and represented by 21 genera with 316 species (ZAhNiser \& DiETrich 2015). The genus was erected by Evans (1977) to accommodate Stenogiffardia elongata Evans, 1977, described from Queensland in Australia. Phrynophyes parvula Kirkaldy, 1906 was recognized as a senior synonym of $S$. elongata by Fletcher \& CONDELlo (1993), and retained in Stenogiffardia. EMELJANov (2002) described another monotypic genus Doraturella, with Doraturella spica Emeljanov, 2002 from Mali as the type species. However, soon after Doraturella was placed in synonymy under Pratura Theron, 1982 (ZAHniser 2008), erected for two South African species - Pratura graminea Theron, 1982 and P. acuminata (Naudé, 1926) (THERON 1982). In the same paper, ZAHNISER (2008) described one more species, P. ceylona Zahniser, 2008, from Sri Lanka. Finally, Pratura and Doraturella were synonymized with Stenogiffardia by ZAHniser (2012). Thus, the genus Stenogiffardia currently comprises five species distributed in Australia, Sri Lanka, Mali, and South Africa. Stenogiffardia has not been known from Madagascar. Below I describe a new species of this genus from central and southwestern Madagascar and remove S. elongata from synonymy.

\section{Material and methods}

Photographs were taken using a Leica MZ9.5 stereomicroscope and a Leica DFC 490 camera. Images were produced using Helicon Focus v. 6.7.1 and Adobe Photoshop software. The genital segments of the specimens examined were macerated in $10 \% \mathrm{KOH}$ and figured in 


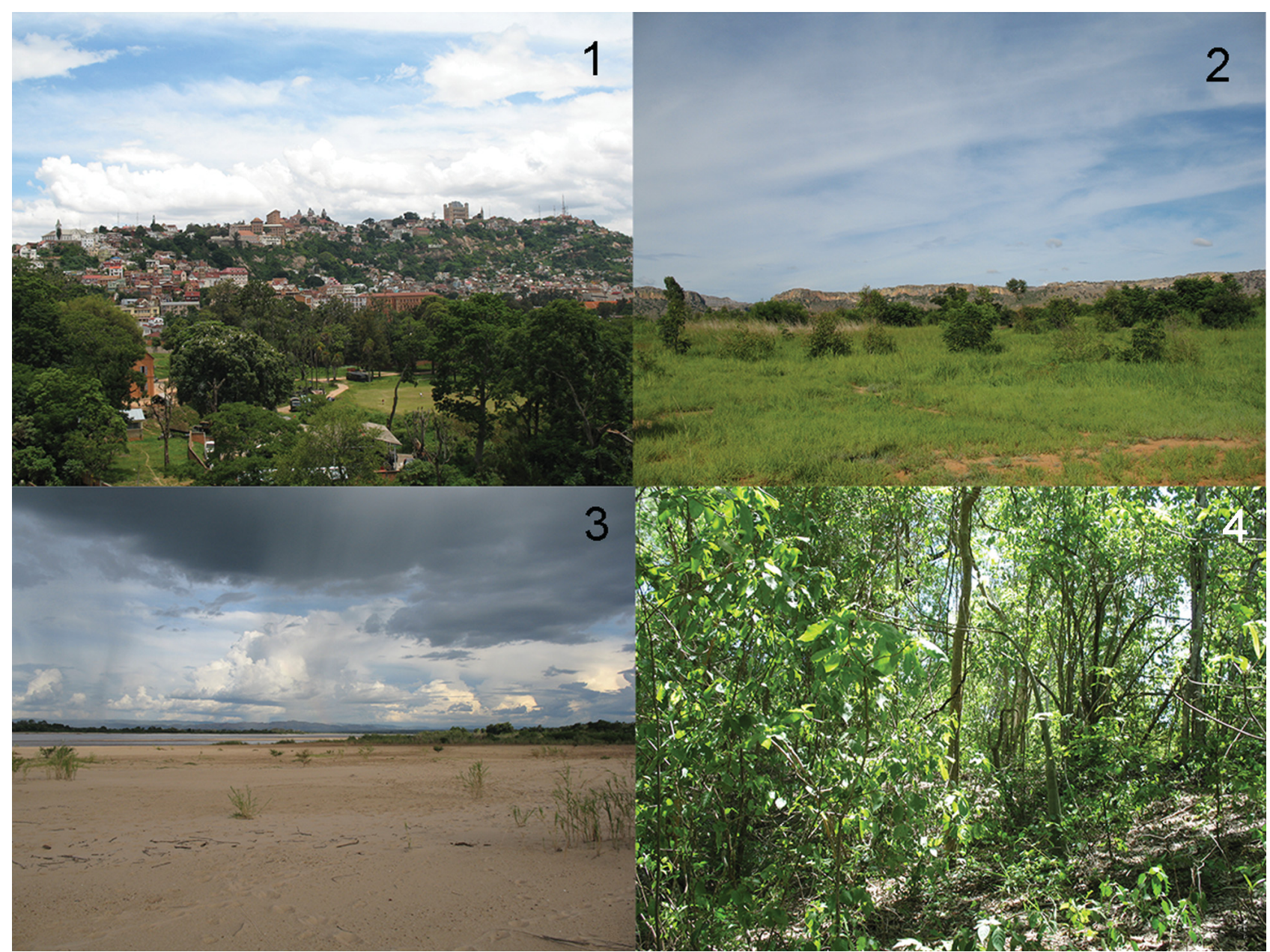

Figs 1-4. Collecting sites of Stenogiffardia bifurca sp. nov. in Madagascar. 1 - Antananarivo; 2 - surroundings of Ranohira; 3 - sand bed of the Mangoky River; 4 - forest in the Makay Massif.

glycerine jelly (Brunel Micro Ltd, UK) using the Leica MZ9.5 stereomicroscope with a camera lucida.

Morphological terminology follows ANUFRIEV \& EMELJANOV (1988).

The type series of the species described below is divided between the Zoological Institute of the Russian Academy of Sciences, Saint Petersburg, Russia (ZIN) and the Muséum national d'Histoire naturelle, Paris, France (MNHN).

\section{Taxonomy}

\section{Stenogiffardia Evans, 1977}

Stenogiffardia Evans, 1977: 116. Type species. Stenogiffardia elongata Evans, 1977, by original designation.

Pratura Theron, 1982: 21. Synonymized with Stenogiffardia by ZAHNISER (2012): 173

Doraturella Emeljanov, 2002: 662. Synonymized with Pratura by ZAHNISER (2008): 6 and with Stenogiffardia by ZAHNISER (2012): 173.

\section{Stenogiffardia bifurca sp. nov.}

(Figs 5-18, 20, 24, 25)

Type locality. Madagascar, former Fianarantsoa Province, Ranohira, $22^{\circ} 33.434^{\prime} \mathrm{S} 45^{\circ} 24.944^{\prime} \mathrm{E}$.

Type material. HolotyPe: $\hat{\delta}$, 'Madagascar, Fianarantsoa / Province, Ranohira / 22³3.434'S 45²4.944'E / 08.i.2011, V. M. Gnezdilov // sweeping of grasses including Cynodon dactylon' (ZIN, dry-mounted, glued on a card label). Paratypes: $2+{ }_{+}$, same data as the holotype (ZIN);
1 , 'Madagascar, Antananarivo / 1854.753'S 47³1.318'E / 06.i.2011, V. M. Gnezdilov // sweeping of grasses along the street' (MNHN); 1 , 'Madagascar, Toliar Province / 21 ${ }^{\circ} 41.001^{\prime} \mathrm{S} 45^{\circ} 08.777^{\prime} \mathrm{E} / \mathrm{Mangoky}$ River, 08.i.2011 / V. M. Gnezdilov // sweeping Cephalostachium sp. on sandy coast' (ZIN); 3 ㅇ, 'Madagascar, Toliar Province / Massif du Makay / $21^{\circ} 35.759^{\prime} \mathrm{S} 45^{\circ} 06.811^{\prime} \mathrm{E} / 12.1 .2011$, V. M. Gnezdilov // sweeping vegetation in dry forest' $\left(\mathrm{ZIN}-299_{+}, \mathrm{MNHN}-19\right)$; all specimens dry-mounted, glued on card labels.

Description. Measurements. Total body length: males 3.5-3.7 mm, females 4.7-5.0 mm.

Coloration. General coloration yellowish green (Figs 5-9). Apex of vertex with a brown spot. Frons light brown in some specimens. Ocelli black. Rostrum, thorax from below, coxae, fore and middle femora, except for apices, and anterior margins of hind femora black. Abdominal sternites III-IV (sometimes III-VI) medially black in females. Abdominal sternites III-IX black, except laterally and posteriorly, in males. Female sternum VII with a wide dark brown median stripe in some specimens. Pygofer basally on dorsal side with a pair of black triangular spots in males and with a dark brown to black transverse stripe and pair of triangular spots in females. Socles of setae on apices of hind tibiae and first and second metatarsomeres dark brown. Claws dark brown. Apices of styles black.

Structure. Head elongate, narrowing apically, with rounded apex (in dorsal view) (Figs 6, 7, 9, 20). Vertex 

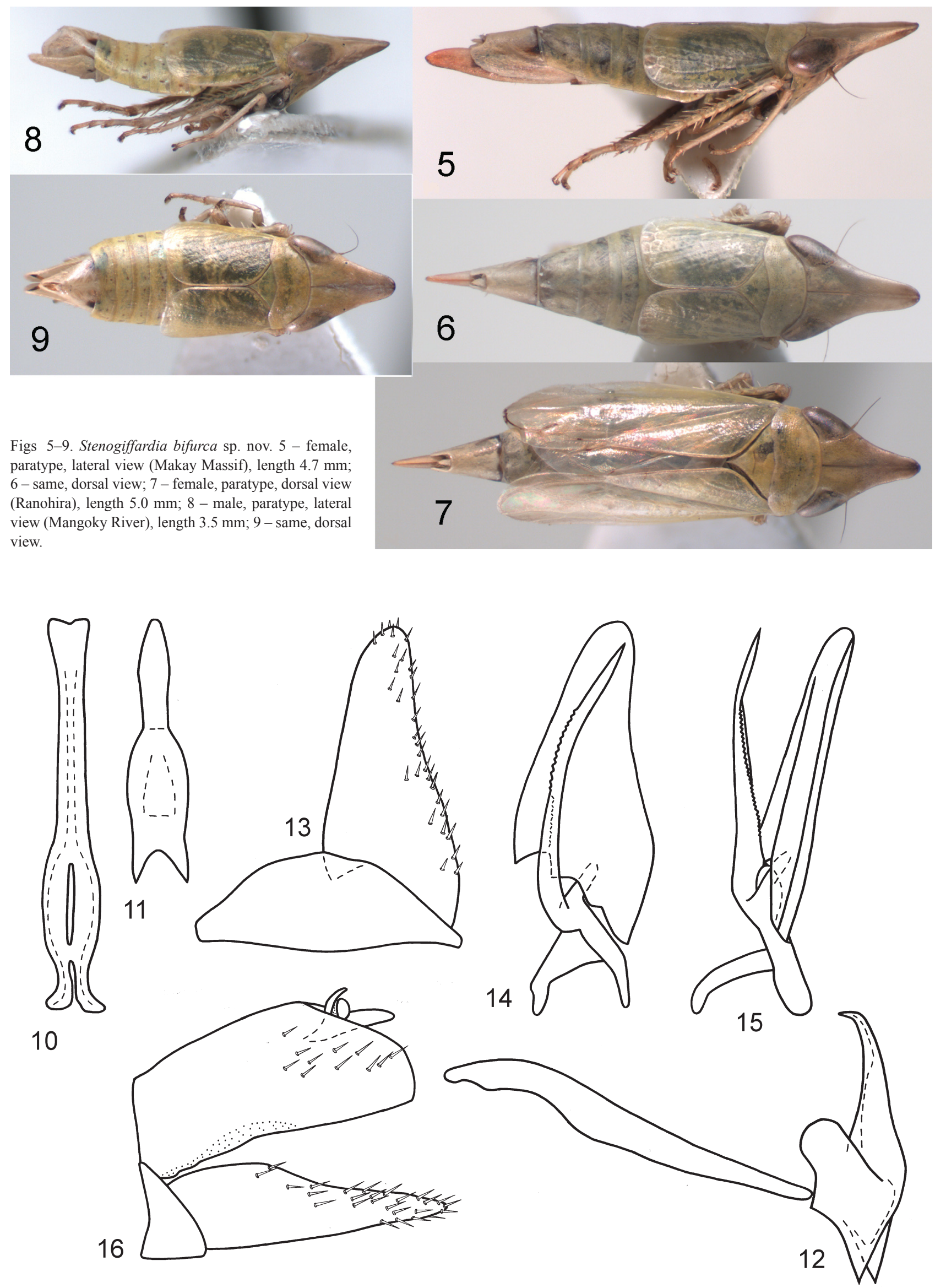

Figs 10-16. Stenogiffardia bifurca sp. nov., holotype, male genitalia. 10 - connective, dorsal view; 11 - aedeagus, ventral view; 12 - aedeagus and connective, lateral view; 13 - genital valve and subgenital plates, ventral view; 14 - subgenital plate with style, dorsal view; 15 - same, lateral view; 16 - anal tube, pygofer, genital valve, and subgenital plates, lateral view. 

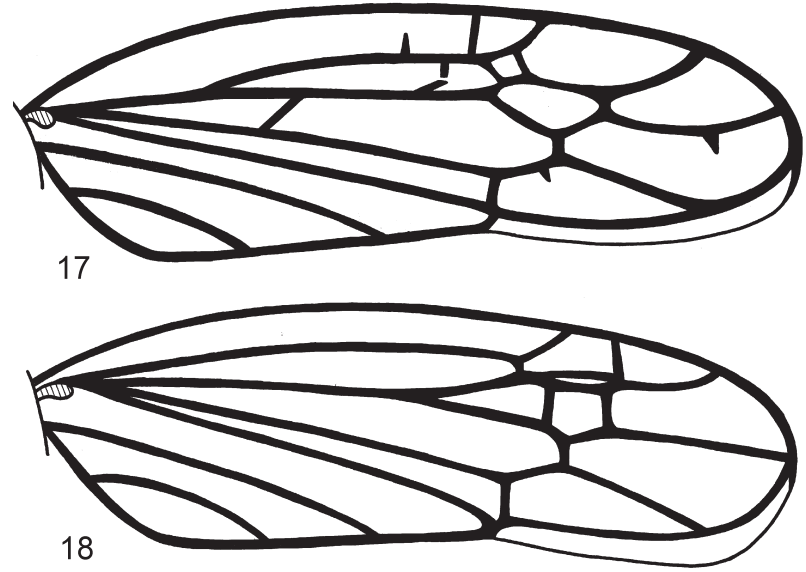

Fig. 17-18. Stenogiffardia bifurca sp. nov., paratype, submacropterous female, fore wings. 17 - right fore wing; 18 - left fore wing. Length of the wings $2.2 \mathrm{~mm}$.

twice (in males) or 2.5 times (in females) as long as wide between eyes, with a weak groove reaching the level of ocelli. Frons without median carina. Rostrum short, apical segment cylindrical. Brachypterous or submacropterous. In brachypterous specimens, fore wings reaching hind margin of tergite V; hind wings oval, rudimentary, half as long as fore wings (Figs 5, 6, 8, 9). In submacropterous female, fore wings reaching hind margin of tergite VIII; hind wings almost as long as fore wings (Fig. 7). Fore wing with 5 apical cells and 3 anteapical cells. In a single submacropterous female examined, right and left fore wings slightly differ in venation: $\mathrm{R} 1-2$, r-m 1-2, M 2-3, im 1-2, m-cua 1-2, CuA 2 (Figs 17, 18). Hind femora with $2+1+1$ (in one female $2+1+1+1)$ macrosetae apically.

Male genitalia (Figs 10-16). Anal tube small. Pygofer lobe with caudal margin at nearly right angle and microsetae nearby (Fig. 16). Genital valve nearly triangular. Subgenital plates as long as pygofer, narrowing apically, with rounded apices and microsetae (Figs 13, 16). Connective long, with stem as long as arms (Figs 10,12). Style with straight, acuminate apex, sharp tooth near the base and a spiraling row of denticles extending subapically (Figs 14, 15). Aedeagus with ventral side strongly bifurcate, evident in caudal view (Figs 11, 12).

Female genitalia (Figs 5-7, 24, 25). Ovipositor protruding far beyond pygofer apex (Figs 5-7). Hind margin of sternite VII convex medially, with two concavities on either side (Figs 24, 25). Brachypterous specimens with a small tooth in each concavity (Fig. 24).

Diagnosis. Aedeagus strongly bifurcate ventrally. Style with straight, acuminate apex.

Etymology. The species name is derived from the Latin adjective bifurcus - two-pronged, referring to the furcation of the ventral side of the aedeagus.

\section{Key to species of Stenogiffardia}

1 Head strongly produced (Figs 19-21). ..................... 2

- Head weakly produced (Figs 22, 23). ...................... 5

2 Vertex rather acuminate apically (Figs 19, 21)........ 3

- Vertex rather rounded apically (Fig. 20). ................. 4

3 Vertex 3.5 times as long as wide between eyes (Fig. 19). Frons with median carina in its apical part (EvANS 1977: fig. 12B). Total length of female (from apex of vertex to apex of ovipositor) $7.0-8.6 \mathrm{~mm}$.

\section{S. elongata Evans, 1977}

- Vertex 2-3 times as long as wide between eyes (Fig. 21). Frons lacking median carina (KIRKALDY 1906: Pl. XXII, fig. 3). Total length of female (from apex of vertex to apex of ovipositor) $6.2 \mathrm{~mm}$.

S. parvula (Kirkaldy, 1906)

4 Style with apex straight (Fig. 14). Aedeagus strongly bifurcate ventrally (Figs 11, 12). Female sternite VII with hind margin convex medially (Figs 24, 25). .......

S. bifurca sp. nov.

- Style with apex bent (Emeljanov 2002: fig. 4). Aedeagus not bifurcate ventrally (EMELJANOv 2002: fig. 8).

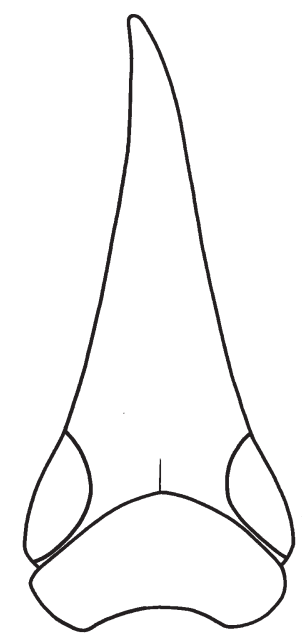

19

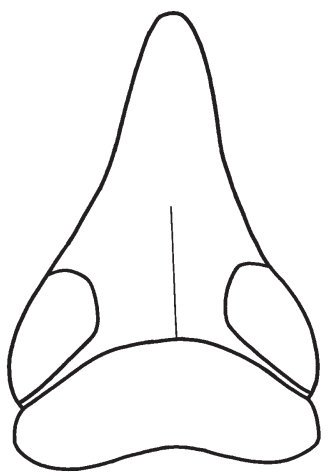

20

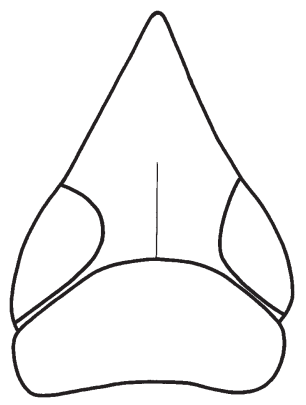

21

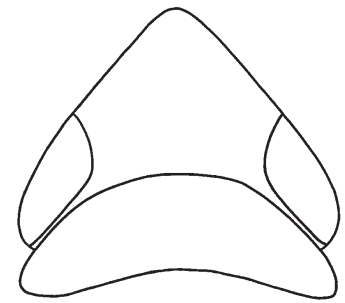

22

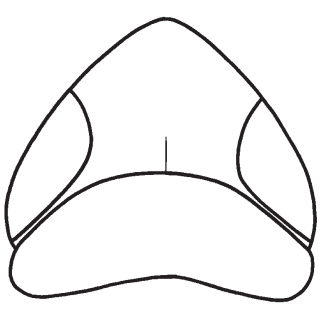

23

Figs 19-23. Stenogiffardia spp., female head and pronotum. 19 - S. elongata Evans, 1977, holotype (after EvANs 1977, modified); 20 - S. bifurca sp. nov., paratype; 21 - S. parvula (Kirkaldy, 1906) (after ZAHNISER 2012, modified); 22 - S. acuminata (Naudé, 1926) (after NAUDÉ 1926, modified); 23 - S. ceylona (Zahniser, 2008), paratype (after ZAHNISER 2008, modified). 


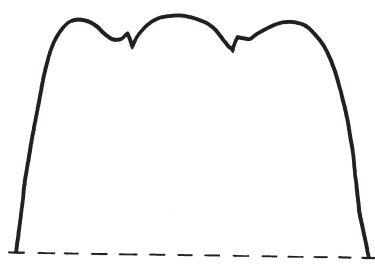

24

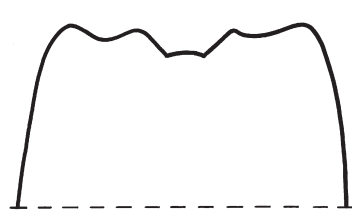

26

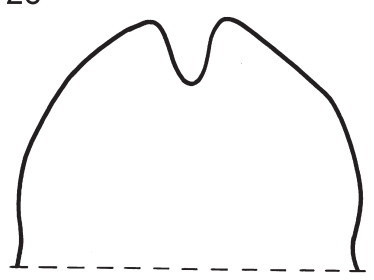

28

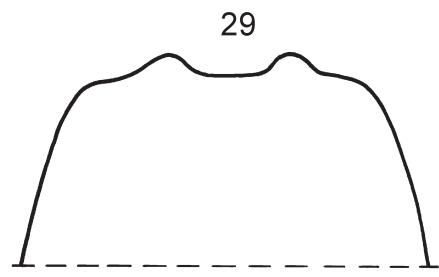

30

Figs 24-30. Stenogiffardia spp., female sternite VII. 24 - S. bifurca sp. nov., paratype, brachypterous specimen; 25 - same, paratype, macropterous specimen; 26 - S. spica (Emeljanov, 2002), paratype; $27-S$. parvula (Kirkaldy, 1906) (after ZAHNISER 2012, modified); 28 - S. ceylona (Zahniser, 2008), paratype (after ZAHNISER 2008, modified); 29-S. graminea (Theron, 1982) (after THERon 1982, modified); 30 - S. acuminata (Naudé, 1926) (after NAudé 1926, modified).

Female sternite VII with hind margin concave medially (Fig. 26).

S. spica (Emeljanov, 2002)

5 Hind margin of female sternite VII with a deep notch medially (Fig. 28).

S. ceylona (Zahniser, 2008)

- Hind margin of female sternite VII with a wide but shallow concavity or a weak notch medially (Figs 29, $30)$.

6 Hind margin of female sternite VII with a wide concavity medially (Fig. 30). Total length of female (from apex of vertex to apex of ovipositor) $3.0 \mathrm{~mm}$.

S. acuminata (Naudé, 1926)

- Hind margin of female sternite VII with a weak notch medially (Fig. 29). Total length of female (from apex of vertex to apex of ovipositor) $4.2-4.7 \mathrm{~mm}$.

S. graminea (Theron, 1982)

\section{Discussion}

The synonymization of Stenogiffardia elongata (Evans, 1977) with Phrynophyes parvula Kirkaldy, 1906 proposed by FletCHER \& CONDELlo (1993) seems unconvincing as females of these taxa illustrated by KIRKALDY (1906: P1.
XXII, figs 1-3), EvANS (1977: figs 12 A-C), and ZAHNISER (2012: figs 7,8) differ from each other in the shape and length of the head - females of S. elongata (Fig. 19) have the vertex distinctly longer than those of $S$. parvula (Fig. $21)$; the apex of vertex of $S$. elongata is also curved and the frons bears a median carina apically (EvANs 1977: figs 12 A, B). The taxa also differ in their body length (KIRKALDY 1906, Evans 1977). Thus, until the male genitalia of $S$. elongata, preferably from its type locality (Richmond, Queensland), are studied and compared with those of $S$. parvula, the lectotype of which was illustrated by FLETCHER \& Condello (1993: figs 11-16), I suggest to treat both species names as valid.

Unfortunately, the male genitalia of $S$. acuminata, described after a single female (NAUDÉ 1926), have not been illustrated either. In the shape of vertex, S. acuminata (Fig. 22; NAUdÉ 1926: pl. V, fig. 2a) is very close to S. graminea (THERON 1982: fig. 37), but these species can be easily separated by the shape of the female sternite VII (Figs 29, 30). Apparently, ZAHNiser (2008: fig. 13) illustrated $S$. acuminata under the name of Pratura graminea. Also, $S$. acuminata seems to be the smallest species in the genus, as NAUDÉ (1926) mentioned $3.0 \mathrm{~mm}$ for the length of the type female, while the females of other Stenogiffardia spp. are larger than $4.0 \mathrm{~mm}$. A further study is needed to make the taxonomic status of these two South African species more clear.

In the elongate but apically rounded vertex, Stenogiffardia bifurca sp. nov. (Fig. 20) is close to S. spica (EMElJanov 2002: figs 1-2). However, in the straight apical part of styles (Figs 14, 15), S. bifurca sp. nov. resembles S. parvula (FLETCHER \& Condello 1993: fig. 13). The other Stenogiffardia spp. have styles with bent apices (Theron 1982: fig. 45; EMELJANov 2002: fig. 4; ZAHNISER 2008: fig. 3). On the other hand, S. bifurca sp. nov. is well distinguished within the genus in its strongly bifurcate base of aedeagus ventrally (Figs 11, 12) and the convex hind margin of female sternite VII medially, with a slight difference in the shape between brachypterous and submacropterous specimens (Figs 24, 25). Other Stenogiffardia spp. have the base of aedeagus rounded, lacking processes ventrally (THERON 1982: fig. 41; FLETCHER \& Condello 1993: figs 14-15; ZAHNiser 2008: fig. 8), and the hind margin of female sternite VII with a medial notch or concavities (Figs 26-30).

The tribe Chiasmini includes many brachypterous and flightless species; most genera are confined to particular biogeographic regions (ZAHNiser \& Dietrich 2015). So far, only two genera of Chiasmini - Exitianus Ball, 1929 and Nephotettix Matsumura, 1902 - have been known from Madagascar (GHAURi 1968, Ross 1968, ZAHNiSER 2008). The finding of Stenogiffardia bifurca sp. nov. in Madagascar once again raises the question on the distribution of predominantly brachypterous and flightless insect taxa in various biogeographic regions across oceanic barriers - in this case, the Mozambique Channel, as other species of Stenogiffardia are known from South Africa and Mali, or even the Indian Ocean - based on the straight apices of the style, S. bifurca sp. nov. might be 
closely related to $S$. parvula from Australia. The origin and diversification of Chiasmini was assumed to happen when the major landmasses had already separated; thus, dispersal, rather than vicariance by the shifting of tectonic plates and separation of major landmasses, is more likely to explain the present global distribution of the tribe (ZAhniser \& Dietrich 2015). A long-distance trans-Atlantic dispersal from Africa into South America was hypothesized by Ross (1968) to explain the origins of the New World Exitianus species and it also received the most support from the analyses by ZAHNISER \& DiETRICH (2015). Similarly, the presence of macropterous species of the genera Exitianus and Nephotettix in Madagascar may be easily explained by a long-distance dispersal by wind from Africa. A similar scenario may also work for Stenogiffardia spp. which are apparently polymorphic for the wing length, with submacropterous females already known for S. elongata (EvAns 1977: fig. 12C) and $S$. bifurca sp. nov. (Fig. 7). Such submacropterous specimens can perhaps fly for a long distance carried by wind. Alternatively, any members of Stenogiffardia may have reached Madagascar with plant rafts carried by ocean currents from the continents or may have even been introduced by humans with any cargo from a still undiscovered source in Asia, Africa or Australia. Human impact has recently been hypothesized to explain the wide range of distribution for some other Deltocephalinae (Eupelicini, Paradorydiina) known from the Mediterranean, Arabian Peninsula, Africa, and Indian subcontinent (GNEZDilov 2019). Apparently, S. bifurca sp. nov. has a wide range of host plants as it was collected in different biotopes, such as from a lawn in the city of Antananarivo, in grasslands, on a sandy river bed, and in the vegetation of the lower tier of dry forest (Figs 1-4); potential host plants are grasses including Cynodon dactylon (L.) Pers. and Cephalostachium sp. Such a wide host-plant range may have facilitated colonization of new habitats.

\section{Acknowledgements}

I am glad to thank Dr. Evrard Wendenbaum (Grenoble, France) and Prof. Thierry Bourgoin (Paris, France) for the opportunity to visit Madagascar, Dr. James N. Zahniser (Washington DC, USA) and Dr. Christopher H. Dietrich (Champaign, Illinois, USA) for their valuable comments on the manuscript and discussion on the wing venation, Dr. Dmitry A. Dmitriev (Champaign, Illinois, USA) for his help with literature, and Dr. R. Razakamalala (Antananarivo, Madagascar) for the identification of Cephalostachium sp. The study was performed in the framework of the Russian State Research project No. AAAA-A19-119020690101-6.

\section{References}

ANUFRIEV G. A. \& EMELJANOV A. F. 1988: Podotryad Cicadinea (Auchenorrhyncha). [Suborder Cicadinea (Auchenorrhyncha).] Pp. 12-495. In: LER P. A. (ed.): Opredelitel' nasekomykh Dal'nego Vostoka SSSR v shesti tomakh. Tom 2. Ravnokrylye i poluzhestkokrylye. [Keys to the insects of the Far East of the USSR in six volumes. Volume II Homoptera and Heteroptera.] Nauka, Leningrad, 972 pp (in Russian).

EMELJANOV A. F. 2002: A new genus and a new species of the tribe Doraturini (Homoptera, Cicadellidae, Deltocephalinae) from Mali. Entomologicheskoe Obozrenie 81: 662-665 (in Russian, English summary).

EVANS J. W. 1977: The leafhoppers and froghoppers of Australia and New Zealand. Part 2. Records of the Australian Museum 31: 83-129.

FLETCHER M. J. \& CONDELLO A. A. 1993: Lectotype designations and new synonymies for GW Kirkaldy's Australian Deltocephalinae (Homoptera: Cicadellidae) held in the BP Bishop Museum, Honolulu. General and Applied Entomology 25: 35-59.

GHAURI M. S. K. 1968: The African and Malagasian species of Nephotettix Matsumura (Homoptera: Cicadelloidea). Bulletin of Entomological Research 57: 643-650.

GNEZDILOV V. M. 2015: [Lost Madagascar.] Priroda 10: $46-53$ (in Russian).

GNEZDILOV V. M. 2019: Leafhoppers of the subtribe Paradorydiina Evans (Hemiptera, Auchenorrhyncha: Cicadellidae) in the United Arab Emirates. Zoosystematica Rossica 28: 155-162.

KIRKALDY G. W. 1906: Leaf-Hoppers and their Natural Enemies (Pt. IX. Leaf-Hoppers - Hemiptera). Report of Work of the Experimental Station of the Hawaiian Sugar Planters' Association, Division of Entomology 1: 271-479, plates XXI-XXXII.

NAUDÉ T. J. 1926: Cicadellidae of South Africa. A taxonomic and faunistic study. Entomology Memoirs 4: 1-106, plates I-X.

ROSS H. H. 1968: The evolution and dispersal of the grassland leafhopper genus Exitianus, with keys to the Old World species (Cicadellidae: Hemiptera). Bulletin of the British Museum (Natural History), Entomology 22: 1-30.

STROIŃSKI A., GNEZDILOV V. M. \& BOURGOIN T. 2011: Sub-brachypterous Ricaniidae (Hemiptera: Fulgoromorpha) of Madagascar with morphological notes for these taxa. Zootaxa 3145: 1-70.

THERON J. G. 1982: Grassland leafhoppers (Hemiptera: Cicadellidae) from Natal, South Africa, with descriptions of new genera and species. Phytophylactica 14: 17-30.

ZAHNISER J. N. 2008: Seven new species and new distributions of Old World Chiasmini (Hemiptera: Cicadellidae: Deltocephalinae), with a redescription, key to genera, and species checklist for the tribe. Zootaxa 1808: 1-32.

ZAHNISER J. N. 2012: New generic synonymies and combinations in Chiasmini (Cicadellidae: Deltocephalinae). International Journal of Tropical Insect Science 32: 173-176.

ZAHNISER J. N. \& DIETRICH C. H. 2013: A review of the tribes of Deltocephalinae (Hemiptera: Auchenorrhyncha: Cicadellidae). European Journal of Taxonomy 45: 1-211.

ZAHNISER J. N. \& DIETRICH C. H. 2015: Phylogeny, evolution, and historical biogeography of the grassland leafhopper tribe Chiasmini (Hemiptera: Cicadellidae: Deltocephalinae). Zoological Journal of the Linnean Society 175: 473-495. 